\title{
Ups and downs in western Crete (Hellenic subduction zone)
}

SUBJECT AREAS:

TECTONICS

GEOMORPHOLOGY

GEOLOGY

Received

5 March 2014

Accepted

10 June 2014

Published

14 July 2014

Correspondence and requests for materials should be addressed to M.M.T. (mara.tiberti@

ingv.it)

\author{
Mara Monica Tiberti, Roberto Basili \& Paola Vannoli
}

Istituto Nazionale di Geofisica e Vulcanologia, Via di Vigna Murata 605, 00143 Rome, Italy.

Studies of past sea-level markers are commonly used to unveil the tectonic history and seismic behavior of subduction zones. We present new evidence on vertical motions of the Hellenic subduction zone as resulting from a suite of Late Pleistocene - Holocene shorelines in western Crete (Greece). Shoreline ages obtained by AMS radiocarbon dating of seashells, together with the reappraisal of shoreline ages from previous works, testify a long-term uplift rate of $2.5-2.7 \mathrm{~mm} / \mathrm{y}$. This average value, however, includes periods in which the vertical motions vary significantly: $2.6-3.2 \mathrm{~mm} / \mathrm{y}$ subsidence rate from 42 ka to 23 ka, followed by $\sim 7.7 \mathrm{~mm} / \mathrm{y}$ sustained uplift rate from $23 \mathrm{ka}$ to present. The last $\sim 5 \mathrm{ky}$ shows a relatively slower uplift rate of 3.0-3.3 mm/y, yet slightly higher than the long-term average. A preliminary tectonic model attempts at explaining these up and down motions by across-strike partitioning of fault activity in the subduction zone.

tudies of past sea-level markers are commonly used to unveil the tectonic history and infer the seismic behavior of subduction zones ${ }^{1-3}$. These studies usually provide estimates of upper-plate long-term uplift trends often with a large variability at the $10^{5}$-year timescale ${ }^{4,5}$. Explanations proposed for this variability include the roughness of the subducting plate and down-dip variations of the locked zone ${ }^{6}$. Vertical motion also manifests sign changes at the timescale of $10^{2}-10^{3}$ years due to the subduction earthquake cycle ${ }^{7}$, and at few-years distance on occasion of distinct earthquakes ${ }^{8}$.

In the Mediterranean Sea, the Hellenic subduction is the one with a supposed capability of generating very large earthquakes and tsunamis. This awareness is mainly brought forward by the historical notion of the 365 AD event $^{9-11}$. In this subduction zone, the island of Crete is one of few accessible places that may provide tectonic information on the overriding plate (Figure 1). In the last $5 \mathrm{My}$, the area has been uplifted by $\sim 1000 \mathrm{~m}^{12}$. In recent times, uplift is testified by raised shorelines and marine terraces in southwestern Crete reported in studies as old as that of Spratt ${ }^{13}$ and recent ones, e.g. Peterek et al. ${ }^{14}$ (and references therein). Nearby Paleochora, several shorelines are recognizable at various elevations; some of them are of Late Pleistocene age and correlated with eustatic peaks (Supplementary Table S1 online). Using these data, the average uplift rate for the last 40-50 ky is estimated at $\sim 1.5 \mathrm{~mm} / \mathrm{y}$ by Wegmann ${ }^{15}$ and $\sim 2 \mathrm{~mm} / \mathrm{y}$ by Shaw et al. ${ }^{16}$. Another estimate at a location $33 \mathrm{~km}$ east of Paleochora is of $1-1.5 \mathrm{~mm} / \mathrm{y}^{17}$.

Besides this net uplift trend, a first indication of both upward and downward movements in Crete is suggested by ten shorelines progressively younger from bottom up and dated between $4800 \mathrm{y} \mathrm{BP}$ (the lowermost) and 1550 y BP (the highest) that testify ten small $(10-20 \mathrm{~cm})$ lowering events, for a total of about $3 \mathrm{~m}^{18}$. These shorelines then became exposed by the up to $\sim 9$-m uplift ascribed to the $365 \mathrm{AD}$ earthquake by Pirazzoli et al. ${ }^{19}$, Shaw et al. ${ }^{16}$, Stiros and Papageorgiou ${ }^{20}$, and Stiros ${ }^{21}$.

In search for additional constraints on the uplift history of the Hellenic subduction, we surveyed the Paleochora shorelines, constrained their age through AMS radiocarbon dating, and then combined these data with paleo sealevel reconstructions for the past $\sim 50 \mathrm{ky}$.

With respect to previous estimates, our results suggest a faster net uplift rate and $10^{4}$-year-long periods of alternating uplift and subsidence, during which the vertical movements are very different from the net average. Although a thorough tectonic explanation of these vertical movements is beyond the scope of this work, this behavior may be explained by across-strike partitioning of tectonic activity (e.g. several subduction earthquake cycles) in the subduction zone. Knowledge of these variations can contribute to better understanding the longterm behavior of the Hellenic subduction zone, and help constrain its earthquake productivity.

\section{Results}

Raised shorelines. The coast of Crete between Krios and Paleochora $(\sim 8 \mathrm{~km})$ preserves a rich set of rather continuous raised shorelines (Figure 2 and Figure 3). Apart from the stretch between Krios and Plakaki, alluvial 


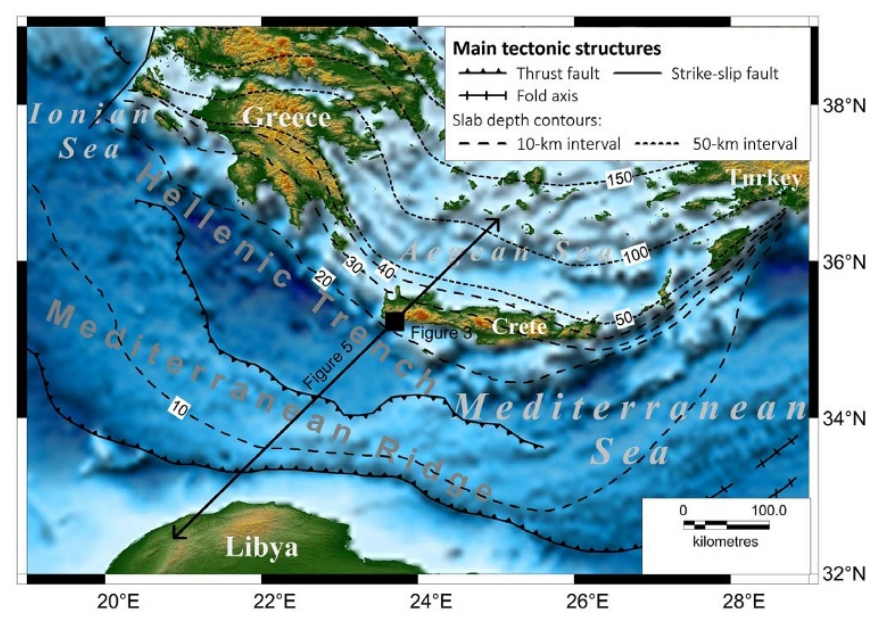

Figure $1 \mid$ Tectonic sketch map of the Hellenic subduction zone. The black square indicates location of the studied coastline nearby Paleochora. Topographic and bathymetric relief are obtained using SRTM V2 (http://www2.jpl.nasa.gov/srtm/) and GEBCO (http://www.gebco.net/) data, respectively.

fans and deep incisions alters the lateral continuity of shorelines only locally. We here illustrate six shoreline remnants, named S1 through S6 from bottom up, irregularly spaced at elevations between 4 and 75 meters (Figure 3; Supplementary Table S2 online), of Late Pleistocene - Holocene age (Table 1; Supplementary Table S3, Figure S1, Figure S2 online).
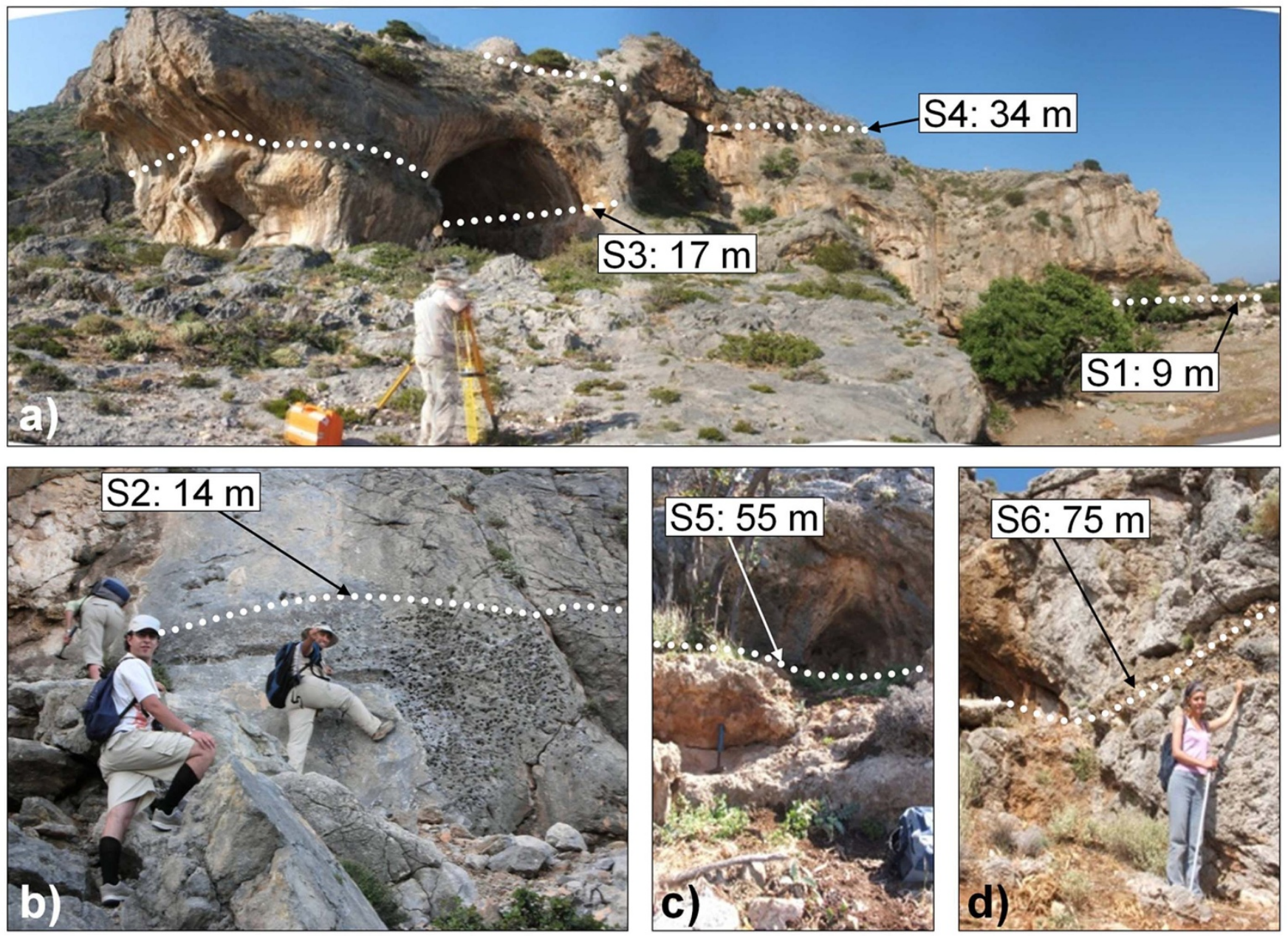

Figure $2 \mid$ Pictures of the surveyed shorelines. Kalamia site notches and their elevations (see Figure 3 for location): (a) Panorama showing three raised shorelines found in the West Kalamia site; (b) A band of lithophagid boreholes marking shoreline S2 in East Kalamia site; (c) S5 shoreline in the West Kalamia site; notice the cave in the background and the sandy-gravel deposit on the foreground; (d) S6 shoreline in the West Kalamia site; notice the cave on the left and the notch carved in the bedrock, filled with gravel. 


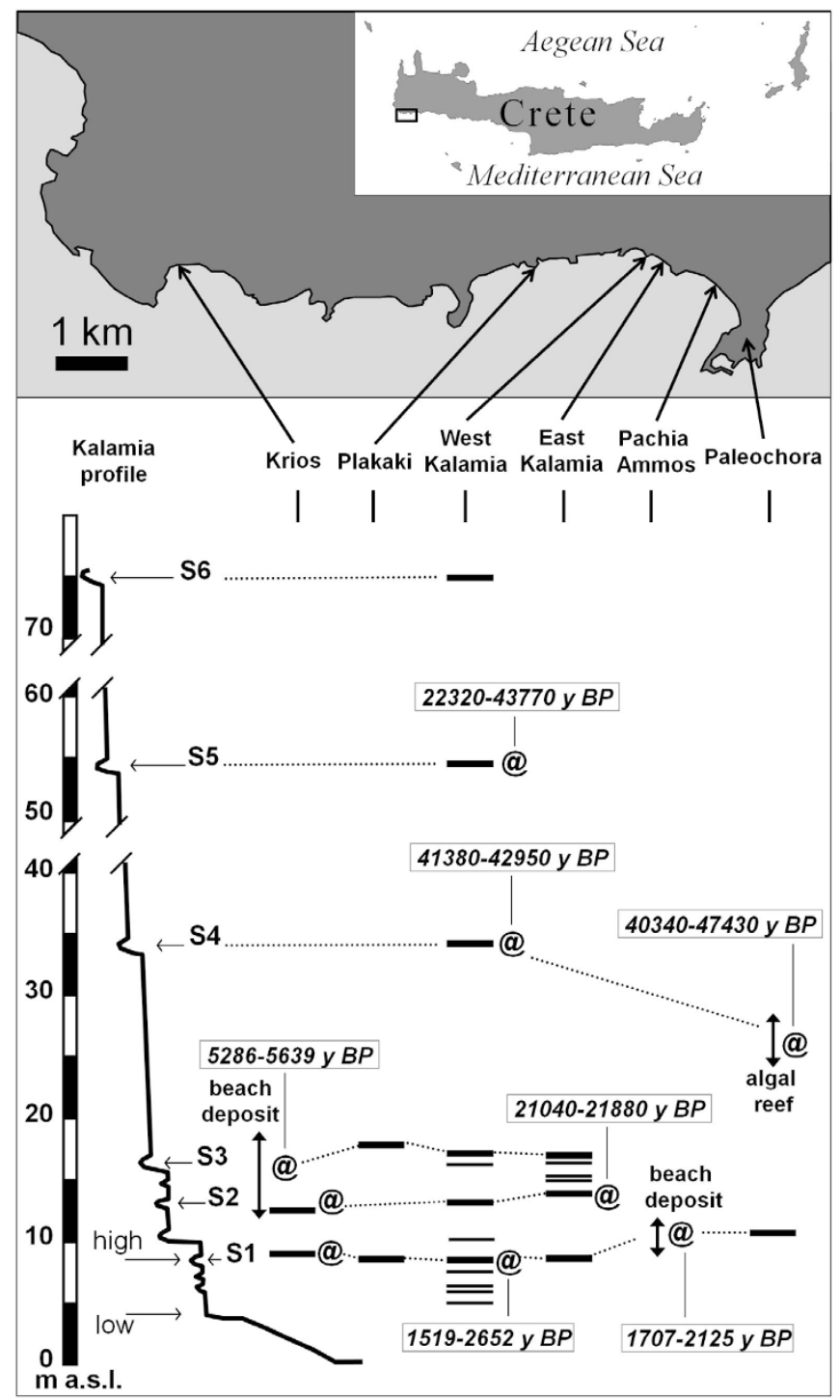

Figure $3 \mid$ Paleochora shoreline suite. Sketch profile of the whole Kalamia site (left) and synoptic view (right) of all the raised shorelines and their ages in the Paleochora broader area; major and minor shoreline features are indicated by thick and thin segments, respectively; vertical extent of sedimentary bodies is indicated by double arrows. Other symbols: @ = fossil finding; dotted line = shoreline correlation.

S1 is very continuous and well exposed and it is actually composed by a suite of several features of different ages. The highest in the suite, denoted S1-high, consists of a notch with algal concretions at $8.34 \mathrm{~m}$ and a surf notch reaching $10 \mathrm{~m}$. At places, remnants of a pebbly beachrock adjoin the main notch, and one such pebbly beach deposit at $8.8-11.8 \mathrm{~m}$ of elevation includes a layer rich in bivalve shells on apparent lateral continuity with an abrasion platform. Several other minor notches are present below the main notch at elevations of 4$8 \mathrm{~m}$. We denote the lowermost notch in this suite as S1-low. AMS ages allow correlation of the entire S1 suite with that described by Pirazzoli et al. ${ }^{18}$ in other parts of Crete (Supplementary Table S2 online).

S3 is located at $16.5 \mathrm{~m}$ and is also very well exposed. It can be followed almost continuously for hundreds of meters and is characterized by a well developed notch and lithophagid boreholes, with adjoining sea arches, caves, and small abrasion platform remnants. Several minor notches can also be seen below the main feature. S3 also features a $\sim 7$-m-thick beach deposit that yielded a bivalve shell of mid-Holocene age.

S2, S4, and S5 are located at elevations of 14, 34, and $55 \mathrm{~m}$, respectively. The age of S2, whose remnants are essentially lithophagid boreholes and a notch, is constrained by a Lithophaga sp. shell dated 21-22 ka. The S4 age of 40-48 ka is consistently provided by four samples. Two of them were found included at the top and bottom of a 1.6-m-thick algal-reef remnant in the Paleochora peninsula, which is geometrically correlated with a gravel deposit at $34 \mathrm{~m}$ elevation on the coastal slope that yielded other two bivalves of about the same age. Conversely, the three samples collected in the gravel associated with S5 are of different ages spanning a considerable time interval of 22-44 ka. The oldest sample was found in loose sediment and can thus be suspected of having been misplaced. S6 is poorly preserved; it only has a small exposure of a notch at $75 \mathrm{~m}$ with sterile gravel and could not be dated.

The analyzed series of shoreline remnants is entirely exposed only at Kalamia. Similar shoreline remnants can also be seen in other parts of Crete but they are not considered in this study.

Average long-term uplift. Sea-level variations for the period of interest $(\sim 50 \mathrm{ky})$, which includes the last three Marine Isotope Stages (MIS), are well represented in the eustatic curve by Waelbroeck et al. ${ }^{22}$ (Supplementary Figure S3 online). However, considering the scatter among curves in different periods $s^{23}$, resorting to specific literature data for each single time interval is necessary. Most authors agree on a $-120 \mathrm{~m}$ sea level during the MIS2 $(\sim 20 \mathrm{ka})$. A recent review for MIS3 $^{24}$ indicates a sea level of 


\begin{tabular}{|c|c|c|c|c|c|}
\hline Code & Shoreline and Locality & Description & d13C & Conv. AMS Age (y BP) & $2 \sigma$ Cal. Age (y BP) \\
\hline $\begin{array}{l}\text { WKB1B } \\
\text { WKB 1A } \\
\text { WPAB41 } \\
\text { WKB4 } \\
\text { KB26A } \\
\text { EKB23 } \\
\text { WKB5 } \\
\text { WKB13 } \\
\text { CA43 } \\
\text { WKB 10 } \\
\text { WKB8 } \\
\text { WKB6 } \\
\text { CA42 }\end{array}$ & $\begin{array}{l}\text { S1; W Kalamia } \\
\text { S1; W Kalamia } \\
\text { S1;P. Ammos } \\
\text { S1; W Kalamia } \\
\text { S3; Krios } \\
\text { S2; E Kalamia } \\
\text { S5; W Kalamia } \\
\text { S5; W Kalamia } \\
\text { S4; Paleochora } \\
\text { S4; W Kalamia } \\
\text { S4; W Kalamia } \\
\text { S5; W Kalamia } \\
\text { S4; Paleochora }\end{array}$ & $\begin{array}{l}\text { Vermetid shell } \\
\text { Spondylus sp. } \\
\text { Bivalve shell } \\
\text { Lithophaga sp. } \\
\text { Bivalve shell } \\
\text { Lithophaga sp. } \\
\text { Bivalve fragment } \\
\text { Bivalve fragment } \\
\text { Bivalve fragment } \\
\text { Bivalve fragments } \\
\text { Glycymeris sp. }^{2} \\
\text { Bivalve fragment }^{4} 5 \\
\text { Bivalve shell }\end{array}$ & $\begin{array}{r}-0.5 \\
-0.9 \\
-8.4 \\
2.5 \\
1.6 \\
-7.6 \\
-3.1 \\
0.1 \\
-8.9 \\
-1.5 \\
0.2 \\
-0.5 \\
-3.5\end{array}$ & $\begin{array}{r}2190 \pm 0.040 \\
2260 \pm 0.040 \\
2348 \pm 0.033 \\
2710 \pm 0.040 \\
5162 \pm 0.039 \\
18400 \pm 0.080 \\
19480 \pm 0.090 \\
26930 \pm 0.160 \\
36993 \pm 0.642 \\
37530 \pm 0.330 \\
38250 \pm 0.350 \\
39190 \pm 0.380 \\
42402 \pm 1.102\end{array}$ & $\begin{array}{c}1519-1933 \\
1591-2029 \\
1707-2125 \\
2142-2652 \\
5286-5639^{\circ} \\
21040-21880 \\
22320-23030 ; 23070-23290^{\circ} \\
30810-31300 \\
40340-42530 \\
41380-42450 \\
41840-42950 \\
42370-43770 \\
43490-47430\end{array}$ \\
\hline
\end{tabular}

$-60 \mathrm{~m}$ in the early part $(\sim 50-60 \mathrm{ka})$ and of $-80 \mathrm{~m}$ in the late part ( 30-50 ka). For the Holocene in Crete, two models exist: 1) same sea level elevation as of today ${ }^{25}$, and 2) sea level 1.25-1.5 m lower than present ${ }^{26}$ at $\sim 6 \mathrm{ka}$.

With respect to these past sea-level elevations, the Paleochora shorelines collectively indicate a net long-term $(\sim 45 \mathrm{ky})$ uplift rate for western Crete of 2.5-2.7 mm/y (Figure 4).

Ups and downs. Are some of the shoreline points in Figure 4 fullfledged indicators of important deviations from the average longterm uplift trend?

Consider first that the age of S4 can be placed in the late MIS3, when sea level was at $-80 \mathrm{~m}$, as constrained by four samples with

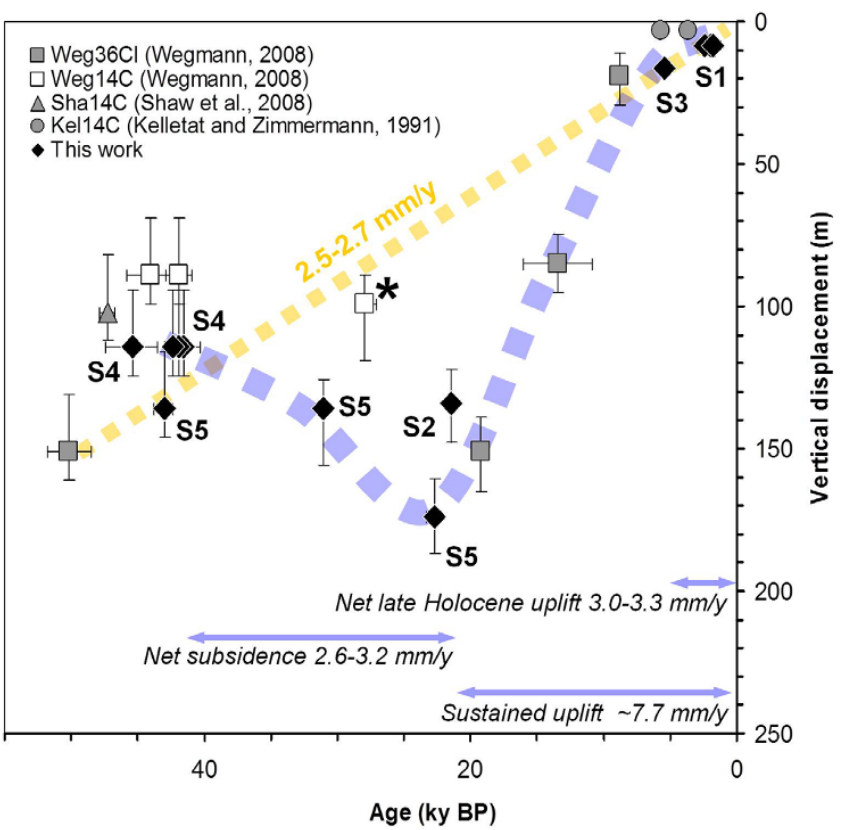

Figure 4 | Vertical displacement vs. shoreline ages. Yellow dashed line represents the long-term average uplift trend; blue dashed line depicts main up-and-down trend. Notice that Kel14C and Sha14C ages are not calibrated. The star symbol marks a sample age discarded by Wegmann ${ }^{15}$ because of contamination. Further details in Supplementary Tables S1 and S3 online. consistent ages (WKB8, WKB10, CA43, and CA42). The oldest age of S5, instead, cannot be accurately traced because of the uncertain placement of WKB6 and sea-level oscillations as large as $20 \mathrm{~m}$ during MIS3, but one can be confident in considering that WKB13 and WKB5 imply that S5 was active in the late MIS3 and early MIS2 with sea level lowering from $-80 \mathrm{~m}$ to $-120 \mathrm{~m}$.

Attaining the S4 to S5 vertical separation thus requires a net subsidence rate of $2.6-3.2 \mathrm{~mm} / \mathrm{y}$ in the period from $\sim 42$ to $23 \mathrm{ky}$ ago. A period of sustained uplift of $\sim 7.7 \mathrm{~mm} / \mathrm{y}$ should have then followed the S5 abandonment ( $\sim 23 \mathrm{ky}$ ago) as suggested by the formation of S2, with sea level at $-120 \mathrm{~m}$, and S3 and S1-low with sea level at about the same elevation as today. Episodic downward movements led to the formation of the other several shorelines of the S1 suite and S1-high itself, which were then all displaced by the uplift event in 365 $\mathrm{AD}^{19,21}$. For what concerns S3, finding of KB26A partly fills the gap of lower-mid Holocene data pointed out by Kelletat ${ }^{27}$ and provides the first evidence for a Holocene shoreline above S1-high. S3 should have been abandoned in a period between the age of KB26A and the age of the oldest shoreline of the S1 suite (Figure 3). From our determinations (Table 1) S1-low has an age of 2142-2652 y BP, thus suggesting the S3 abandonment to have occurred within $2142-5639$ y BP. This time range, however, could likely be much shorter if considering that S1-low is younger than shoreline VIII ${ }^{19}$, found at $4 \mathrm{~m}$ in Phalasarna (Crete western coast), whose age is $4410-5070 \mathrm{y} \mathrm{BP}^{19}$. The net lateHolocene uplift rate in Crete is slightly different depending on which of two sea-level models is adopted for the time of S3 abandonment. The uplift rate would be $3 \mathrm{~mm} / \mathrm{y}$ according to sea level as in the work by Pirazzoli ${ }^{25}$; whereas it would be $3.3 \mathrm{~mm} / \mathrm{y}$ according to sea level as in the work by Lambeck and Purcell ${ }^{26}$.

Preliminary tectonic model. Mature accretionary convergent margins are known to develop distinct kinematic domains acrossstrike which can also host splay faults. Along-dip partitioning of the slab itself are also documented in subduction zones and have been explained by various driving mechanisms ${ }^{28}$. In the Hellenic subduction, the best known uplift event in Crete, i.e. the event associated with the $365 \mathrm{AD}$ earthquake, has either been related to seismic slip on the subduction interface $e^{29,30}$ or on a shallower crustal fault embedded into the accretionary wedge ${ }^{16,21}$. Building on this knowledge and as a preliminary attempt to explain the reconstructed vertical motions, we envisage that $10^{4}$-year timescale rate variations can be explained by fault activity partitioning across the subduction zone. To this end, we subdivide the subduction zone into two separate sections, front and rear, across the main slab dip 


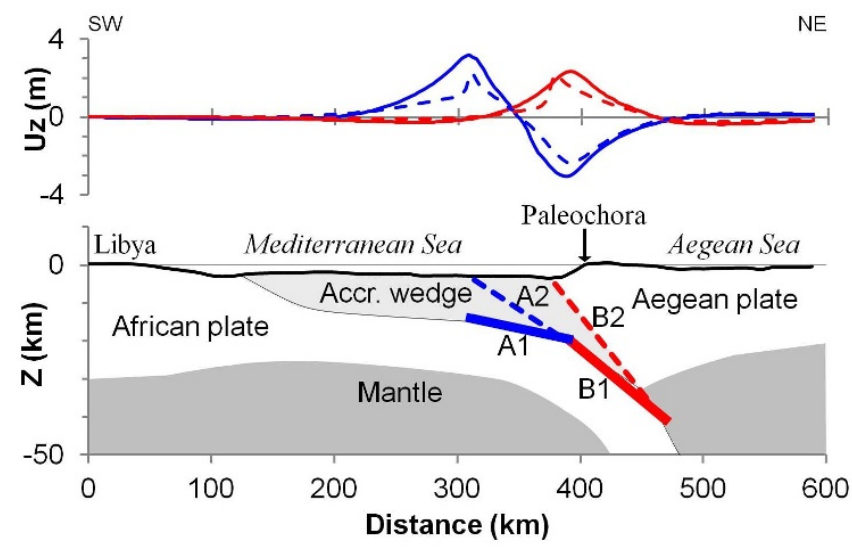

Figure $5 \mid$ Fault dislocation model. Steady-state ( $\mathrm{t}$ - > infinity) surface displacement pattern $(\mathrm{Uz})$ along profile shown in Figure 1 due to faulting in a viscoelastic-gravitational medium ${ }^{43}$. We hypothesize four equal-size fault ruptures (roughly moment magnitude 8 ) at the front and rear of the slab main dip change (vertical exaggeration $\sim 2.5 \times$ ). Front section: A1, interface (solid blue); A2, splay (dashed blue). Rear section: B1, interface (solid red); B2, splay (dashed red). More modeling details are shown in Supplementary Tables S5, S6, and S7 online. Notice that the relative fault rupture positions and the fault dip angles determine vertical movements of opposite sign at the observation point (Paleochora).

change and set up a series of four distinct dislocation models which include fault slip on the subduction interface and on prospective splay faults (Figure 5).

Based on these fault-dislocation models, we suggest that periods of enhanced uplift rates at Paleochora occur when activity in the subduction rear section dominates (i.e. when the fault activity mainly occurs beneath Crete, as in the case of the $365 \mathrm{AD}$ earthquake). When considering splay ruptures through the upper plate the uplift trend is further emphasized. Because of their high dip angle these faults mainly produce uplift and limited subsidence. Conversely, stability or lowering at Paleochora occurs when the fault activity primarily involves the subduction front section (i.e. south of Crete) including shallow splay faults within the accretionary wedge. Persistence of this activity can explain both the lowering episodes recorded by the S1 suite $^{18}$ and the subsidence between S4 and S5. Because of their low dip angle, these faults produce significant subsidence in Crete and uplift offshore south of Crete.

The alternating phases of uplift and subsidence recorded by the raised shorelines on the coast of Crete may thus reflect backward and forward shifting of tectonic activity across the Hellenic subduction system as also observed at a different timescale in other subduction zones (e.g. Solomon Islands ${ }^{8}$ ).

\section{Discussion}

Major uncertainties in our reconstruction of the Paleochora shoreline suite are represented by the measure of their elevation and spatial correlation, and the sample age determination and sampling site conditions. Shoreline elevations are measured by a geodimeter whose accuracy, together with the small tidal range in Crete, ensure an overall elevation uncertainty of well developed notches to remain within less than $\pm 10 \mathrm{~cm}$. Uncertainty can be occasionally higher for gravel deposits or other coarse shoreline features. The short horizontal distance that separates most remnants allows us considering the lateral correlation based on geomorphic criteria to be relatively robust. We cannot exclude that the algal reef in the Paleochora peninsula can be correlated with S5 but this alternative would not affect our interpretation of the results. X-ray diffraction analysis shows that radiocarbon ages are not affected by calcite recrystallization. The small percentage of calcite $(<5 \%)$ in KB26A, WKB8, and WKB10
(Supplementary Figure S2, Table S3 online) may indicate secondary recrystallization but not necessarily alteration of their radiocarbon age. As for KB26A, the effect of contamination would result in rejuvenating its age of at maximum $200 \mathrm{y}$. Accordingly, the older bound of its calibrated age may be extended to $\sim 5880$ y BP. Considering that real ages of Lithophaga sp. shells can be up to 2 ky younger than their radiocarbon age ${ }^{31}$, the younger bound of EKB23 calibrated age could be up to $\sim 19 \mathrm{ka}$. The site conditions (Supplementary Table S2 online) indicate a strong bond between samples and shoreline in all cases except for WKB6, suggesting that its age is not totally reliable to ascertain the age of S5.

The accuracy of uplift rate estimates is affected by all the above uncertainties along with uncertainties about past sea-level elevations $^{23}$. Our net long-term ( $\left.\sim 45 \mathrm{ky}\right)$ uplift rate estimate of 2.5$2.7 \mathrm{~mm} / \mathrm{y}$ (Figure 4) is higher than the uplift rate $(\sim 2 \mathrm{~mm} / \mathrm{y})$ obtained by Shaw et al. ${ }^{16}$ which consider an elevation of the Paleochora terrace of $24 \mathrm{~m}$ instead of the inner edge elevation of $34 \mathrm{~m}$ resulting from our survey (Supplementary Table S2 online). The average uplift rate proposed by Wegmann ${ }^{15}$, instead, is significantly lower $(\sim 1.5 \mathrm{~mm} / \mathrm{y})$ than our estimate. We note that this value is mainly based on the correlation of a shoreline at $9 \mathrm{~m}$ elevation (likely S1-high in our work) with MIS3. However, these differences are relatively small compared with the uncertainty in sea-level elevation at the time of shoreline formation or abandonment and mainly depend on interpretations of individual shorelines. Nonetheless, the reconstructed pattern of ups and downs clearly deviates from the average trend (Figure 4) supporting the idea that vertical displacement in Crete may strongly fluctuate over a $10^{4}$-year timescale. For completeness of information, we note that some other shoreline ages nearby Paleochora (Supplementary Table S1 online) are difficult to reconcile with our reconstruction. For example, Kelletat and Zimmermann $^{32}$ provided an uncalibrated age of $5.735 \pm 90 \mathrm{ky}$ BP for an algal rim at $3.3 \mathrm{~m}$, at Kalamia, $13 \mathrm{~m}$ below S3; Kelletat et al. ${ }^{33}$ determined an ESR age of 113-114 ka for two samples collected at 2.5 m elevation; and Wegmann ${ }^{15}$ determined a radiocarbon age of 41-46 ka for the shoreline at $9 \mathrm{~m}$ elevation. However, Wegmann ${ }^{15}$ also provided ${ }^{36} \mathrm{Cl}$ exposure ages for some raised shorelines around Paleochora that, when combined with the eustatic curve, fit quite well with our reconstruction (Figure 4).

Because of the dominating role of convergence in the Hellenic subduction, our preliminary tectonic model only focuses on fault activity in the subduction zone and neglects possible contributions from other processes, such as the crustal extension in the upper plate (see for example modeled geodetic rates from Reilinger et al. ${ }^{34}$ ). Nor have we investigated the role of the various driving mechanisms of fault activity in the subduction system (see Kopp ${ }^{28}$ for a review). Nonetheless, at this stage of the analysis we propose a simple model that together with our findings shows that tectonic rates may vary depending on both timescale and location of the observation point with respect to the subduction architecture. As we progressively unveil vertical tectonic rate fluctuations at various timescale in subduction zones, the analysis of raised shorelines proves to be an effective tool to improve our understanding of long-term processes which complement other observables such as decadal instrumental measurements. In this perspective, detailed shoreline analyses can shed light on maximum deviations of tectonic rates with respect to longterm averages. Since earthquake productivity estimates can be derived from tectonic rates (e.g. Geist and Parsons ${ }^{35}$ ), a compelling implication in active subduction zones is that earthquake rates may considerably vary as a function of location and time interval considered.

\section{Methods}

Shoreline identification. Raised shorelines are identified by coastal notches, lithophagid boreholes, sea caves, coastal terraces, abrasion platforms, and sand-togravel beach deposits. Their present elevations are measured through geodimeter land surveying. Correlation of individual shoreline remnants is initially based on 
geomorphic criteria and then confirmed/refined through AMS radiocarbon ages where applicable.

Shoreline ages. The AMS radiocarbon technique is used for dating seashells or encrusting organisms sampled directly from the shoreline feature. X-ray diffraction analysis (XRD) of the inner parts of dated samples is used to verifying the preservation of the original aragonite phase of shells ${ }^{36}$. Pretreatment of samples includes mechanical and chemical removal of the outer portion in order to limit the effects of external contamination. Calibration of radiocarbon ages is carried out using INTCAL09 Marine Calibration dataset ${ }^{37}$ with the Calib 6.0 software () $1986-2011$ : Minze Stuiver and Paula Reimer) and, following recommendations by Reimer and McCormac ${ }^{38}$, by taking into account the local reservoir offset from the modeled world ocean $(\Delta R)$ by applying a value of $\Delta R=46 \pm 77 \mathrm{y}$ as the Mediterranean average (Marine Reservoir Correction Database, http://calib.qub.ac.uk/marine/, last accessed March 3rd, 2014; using data from various sources ${ }^{38-41}$, including a pers. comm. to the authors of the Database by Taviani and Correggiari; Supplementary Table S4 online). Laboratory error multiplier equal to 1 has been applied to all samples. When discussing radiocarbon ages taken from the literature we refer to values that are calibrated or re-calibrated in this same way.

Shoreline displacement rates. Radiocarbon ages are used for the chronological correlation of shorelines with the eustatic curve and MISs (Supplementary Figure S3 online). We assume that a shoreline or terrace may form during any time when sea level and tectonic variations were about equal ${ }^{42}$, then obtain the net shoreline displacement by subtracting the eustatic elevation at the time of formation/ abandonment from the measured shoreline elevation. Vertical displacement of shorelines is defined as $\Delta U=H-\Delta E$, where: $\Delta U$ is the calculated displacement, $H$ is the measured shoreline elevation above present sea level, and $\Delta E$ is the difference between present mean sea level and sea-level elevation (eustatic) at the estimated time of shoreline formation. Vertical displacement rates (either uplift or subsidence) are obtained by averaging the ratio between vertical separation of shorelines and the intervening time in a period of interest, such as $U R=\left(\Delta U_{n}-\Delta U_{n-1}\right) / T_{n}-T_{n-1}$ where: $U R$ is the calculated displacement rate in the time interval $T_{n}-T_{n-1} ; \Delta U_{n}$ and $T_{n}$ are the calculated displacement and the age of shoreline $n$, respectively.

Preliminary tectonic modeling. To explore the vertical component of the surface displacement patterns along a profile normal to subduction strike and through Paleochora (Figure 5) we make use of viscoelastic-gravitational fault-dislocation modeling ${ }^{43}$. All faults are purely reverse, and strike orthogonally to profile in Figure 1 with dip toward NE according to the local slab geometry ${ }^{44}$; they have the same size and amount of slip as to represent a magnitude- 8 earthquake compatible with appropriate scaling laws for slab interfaces ${ }^{45}$ and crustal faults ${ }^{46}$. Modeling setup details are shown in Supplementary Tables S5, S6, S7 online. Supplementary Figures S4 and S5 online also show profiles of both coseismic and steady-state displacement for the front and rear sections of the subduction zone.

1. Shimazaki, K. \& Nakata, T. Time-predictable recurrence model for large earthquakes. Geophys. Res. Lett. 7(4), 279-282 (1980).

2. Sieh, K. et al. Earthquake supercycles inferred from sea-level changes recorded in the corals of West Sumatra. Science 322, 1674-1678, doi: 10.1126/science.1163589 (2008).

3. Berryman, K. et al. Holocene paleoseismic history of upper-plate faults in the southern Hikurangi subduction margin, New Zealand, deduced from marine terrace records. B. Seismol. Soc. Am. 101(5), 2064, doi: 10.1785/0120100282 (2011).

4. Ota, Y. \& Yamaguchi, M. Holocene coastal uplift in the western Pacific Rim in the context of late Quaternary uplift. Quatern. Int. 120, 105-117, doi: 10.1016/ j.quaint.2004.01.010 (2004)

5. Ramirez-Herrera, M. T., Kostoglodov, V. \& Urrutia-Fucugauchi, J. Overview of Recent Coastal Tectonic Deformation in the Mexican Subduction Zone. Pure Appl. Geophys. 168(8-9) 1415-1433, doi: 10.1007/s00024-010-0205-y (2011).

6. Saillard, M. et al. Non-steady long-term uplift rates and Pleistocene marine terrace development along the Andean margin of Chile $\left(31^{\circ} \mathrm{S}\right)$ inferred from $10 \mathrm{Be}$ dating. Earth Planet. Sc. Lett. 277, 50-63, doi: 10.1016/j.epsl.2008.09.039 (2009).

7. Meltzner, A. J. et al. Coral evidence for earthquake recurrence and an A.D. 13901455 cluster at the south end of the 2004 Aceh-Andaman rupture. J. Geophys. Res. Solid Earth 115, B10402, doi: 10.1029/2010JB007499 (2010).

8. Newman, A. V. et al. The energetic 2010 MW 7.1 Solomon Islands tsunami earthquake. Geophys. J. Int. 186, 775-781, doi: 10.1111/j.1365-246X.2011.05057.x. (2011).

9. Guidoboni, E., Comastri, A. \& Traina, G. Catalogue Of Ancient Earthquakes In The Mediterranean Area Up To The 10th Century. SGA, Istituto Nazionale di Geofisica (1994)

10. Stiros, S. \& Drakos, A. A fault-model for the tsunami-associated, magnitude $\geq 8.5$ Eastern Mediterranean, AD365 earthquake. Z. Geomorphol. 146, 125-137 (2006).

11. Polonia, A. et al. Mediterranean megaturbidite triggered by the AD 365 Crete earthquake and tsunami. Sci. Rep. 3, 1285, doi: 10.1038/srep01285 (2013).

12. Zachariasse, W. J., van Hinsbergen, D. J. J. \& Fortuin, A. R. Mass wasting and uplift on Crete and Karpathos during the early Pliocene related to initiation of south Aegean left-lateral, strike-slip tectonics. Geol. Soc. Am. Bull. 120, 976-993, doi: 10.1130/b26175.1 (2008).
13. Spratt, T. A. B. Travels And Researches In Crete. London, J. van Voorst, Paternoster Row (1865)

14. Peterek, A., Beneke, K., Schwarze, J. \& Spinn, A. Küste und Küstenformung in Westkreta als Spiegelbild eustaticher, tektonischer und gravitativ-tektonischer Prozesse. Essener Geog. Arb. 35, 39-56 (2003).

15. Wegmann, K. W. Tectonic geomorphology above Mediterranean subduction zones: northeastern Apennines of Italy and Crete, Greece. Ph.D. Thesis, Bethlehem, Pennsylvania, Lehigh University, 169 p. (2008).

16. Shaw, B. et al. Eastern Mediterranean tectonics and tsunami hazard inferred from the AD 365 earthquake. Nature Geosci. 1, 268-276, doi: 10.1038/ngeo151 (2008).

17. Strasser, T. F. et al. Dating Palaeolithic sites in southwestern Crete, Greece. J. Quaternary Sci. 26, 553-560, doi: 10.1002/jqs.1482 (2011).

18. Pirazzoli, P. A., Thommeret, J., Thommeret, Y., Laborel, J. \& Montaggioni, L. F. Crustal block movements from holocene shorelines: Crete and antikythira (Greece). Tectonop. 86, 27-43, doi: 10.1016/0040-1951(82)90060-9 (1982).

19. Pirazzoli, P. A., Laborel, J. \& Stiros, S. C. Earthquake clustering in the Eastern Mediterranean during historical times. J. Geophys. Res. 101, 6083-6097, doi: 10.1029/95JB00914 (1996).

20. Stiros, S. \& Papageorgiou, S. Seismicity of Western Crete and the destruction of the town of Kisamos at AD 365: Archaeological evidence. J. Seismol. 5, 381-397, doi: 10.1023/A:1011475610236 (2001).

21. Stiros, S. C. The 8.5+ magnitude, AD365 earthquake in Crete: Coastal uplift, topography changes, archaeological and historical signature. Quatern. Int. 216, 54-63, doi: 10.1016/j.quaint.2009.05.005 (2010).

22. Waelbroeck, C. et al. Sea-level and deep water temperature changes derived from benthic foraminifera isotopic records. Quaternary Sci. Rev. 21, 295-305, doi: 10.1016/S0277-3791(01)00101-9 (2002).

23. Caputo, R. Sea-level curves: Perplexities of an end-user in morphotectonic applications. Global Planet. Change 57(3), 417-423 (2007)

24. Siddall, M., Rohling, E. J., Thompson, W. G. \& Waelbroeck, C. Marine isotope stage 3 sea level fluctuations: Data synthesis and new outlook. Rev. Geophys. 46 RG4003, doi: 10.1029/2007RG000226 (2008).

25. Pirazzoli, P. A. A review of possible eustatic, isostatic and tectonic contributions in eight late-Holocene relative sea-level histories from the Mediterranean area. Quaternary Sci. Rev. 24, 1989-2001, doi: 10.1016/j.quascirev.2004.06.026 (2005).

26. Lambeck, K. \& Purcell, A. Sea-level change in the Mediterranean Sea since the LGM: model predictions for tectonically stable areas. Quaternary Sci. Rev. 24, 1969-1988, doi: 10.1016/j.quascirev.2004.06.025 (2005).

27. Kelletat, D. Perspectives in Coastal Geomorphology of Western Crete, Greece. Supplementband Z. Geomorphol. 102, 1-19 (1996).

28. Kopp, H. Invited review paper: The control of subduction zone structural complexity and geometry on margin segmentation and seismicity. Tectonoph. 589, 1-16, doi: 10.1016/j.tecto.2012.12.037 (2013).

29. Papadimitriou, E. \& Karakostas, V. Rupture model of the great AD 365 Crete earthquake in the southwestern part of the Hellenic Arc. Acta Geophys. 56, 293-312, doi: 10.2478/s11600-008-0001-6 (2008).

30. Ganas, A. \& Parsons, T. Three-dimensional model of Hellenic Arc deformation and origin of the Cretan uplift. J. Geophys. Res. 114, B06404, doi: 10.1029/ 2008JB005599 (2009).

31. Shaw, B., Jackson, J. A., Higham, T. F. G., England, P. C. \& Thomas, A. L. Radiometric dates of uplifted marine fauna in Greece, Implications for the interpretation of recent earthquake and tectonic histories using lithophagid dates. Earth Planet. Sc. Lett. 297, 395-404, doi: 10.1016/j.epsl.2010.06.041 (2010).

32. Kelletat, D. \& Zimmermann, L. Verbreitung und Formtypen rezenter und subrezenter organischer Gesteinsbildungen an den Küsten Kretas. Essener Geog Arb. 23 (1991).

33. Kelletat, D., Schellmann, G. \& Brückner, H. Erste absolute Datierungen pleistozäner Litoralbindungen der Insel Kreta, Griechenland. Marbg. Geogr. Schr 134, 85-100 (1999).

34. Reilinger, R. et al. GPS constraints on continental deformation in the AfricaArabia-Eurasia continental collision zone and implications for the dynamics of plate interactions. J. Geophys. Res. 111, B05411, doi: 10.1029/2005JB004051 (2006).

35. Geist, E. L. \& Parsons, T. Probabilistic Analysis of Tsunami Hazards. Nat. Hazards 37, 277-314, doi:10.1007/s11069-005-4646-z (2006).

36. Douka, K., Higham, T. F. G. \& Hedges, R. E. M. Radiocarbon dating of shell carbonates: old problems and new solutions. Munibe 31, 18-27 (2010).

37. Reimer, P. J. et al. IntCal09 and Marine09 radiocarbon age calibration curves, 0 50,000 years cal BP. Radiocarbon 51, 1111-1150 (2009).

38. Reimer, P. J. \& McCormac, F. G. Marine radiocarbon reservoir corrections for the Mediterranean and Aegean Seas. Radiocarbon 44(1), 159-166 (2002).

39. Boaretto, E., Mienis, H. K. \& Sivan, D. Reservoir age based on pre-bomb shells from the intertidal zone along the coast of Israel. Nucl. Instr. Meth. Phys. Res. B 268, 966-968, 10.1016/j.nimb.2009.10.075 (2010).

40. Langone, L., Asioli, A., Corregiari, A. \& Trincardi, F. Age-depth modelling through the late Quaternary deposits of the central Adriatic basin. Mem. Ist. Ital. Idrobiol. 55, 177-196 (1996).

41. Siani, G. et al. Radiocarbon reservoir ages in the Mediterranean Sea and Black Sea. Radiocarbon 42(2), 271-280 (2000).

42. Lambeck, K. \& Chappell, J. Sea Level Change Through the Last Glacial Cycle. Science 292, 679-686, doi: 10.1126/science.1059549 (2001). 
43. Wang, R., Lorenzo-Martin, F. \& Roth, F. PSGRN/PSCMP-a new code for calculating co- and post-seismic deformation, geoid and gravity changes based on the viscoelastic-gravitational dislocation theory. Comput. Geosci. 32, 527-541, doi: 10.1016/j.cageo.2005.08.006 (2006).

44. Basili, R. et al. The European Database of Seismogenic Faults (EDSF) compiled in the framework of the Project SHARE. http://diss.rm.ingv.it/share-edsf/, doi: 10.6092/INGV.IT-SHARE-EDSF (2013).

45. Strasser, F. O., Arango, M. C. \& Bommer, J. J. Scaling of the source dimensions of interface and intraslab subduction-zone earthquakes with moment magnitude. Seismol. Res. Lett. 81(6), 941-950, doi: 10.1785/gssrl.81.6.941 (2010).

46. Leonard, M. Earthquake Fault Scaling: Self-Consistent Relating of Rupture Length, Width, Average Displacement, and Moment Release. B. Seismol. Soc. Am. 100(5A), 1971-1988, doi: 10.1785/0120090189 (2010).

\section{Acknowledgments}

Authors thank M.M.C. Carafa for fieldwork assistance; P.A. Pirazzoli for insights on shorelines of western Crete; G.B. Andreozzi and S. Stellino for XRD analyses; T. Goszlar and D. Hood for helping in interpreting radiocarbon dating; F. Bernardi for translating German literature; S. Silenzi (sadly passed away in 2012) for discussions on eustatic curves.

\section{Author contributions}

M.M.T.: field work, preparation of samples, review of literature data, data analysis and interpretation of results, manuscript preparation; R.B.: initial idea and work planning, field work, interpretation of results, manuscript preparation; P.V.: field work, preparation of samples, review of literature data. All authors commented on the manuscript.

\section{Additional information}

Supplementary information accompanies this paper at http://www.nature.com/ scientificreports

Competing financial interests: The authors declare no competing financial interests

How to cite this article: Tiberti, M.M., Basili, R. \& Vannoli, P. Ups and downs in western Crete (Hellenic subduction zone). Sci. Rep. 4, 5677; DOI:10.1038/srep05677 (2014).

This work is licensed under a Creative Commons Attribution-NonCommercialShareAlike 4.0 International License. The images or other third party material in this article are included in the article's Creative Commons license, unless indicated otherwise in the credit line; if the material is not included under the Creative Commons license, users will need to obtain permission from the license holder in order to reproduce the material. To view a copy of this license, visit http:// creativecommons.org/licenses/by-nc-sa/4.0/ 